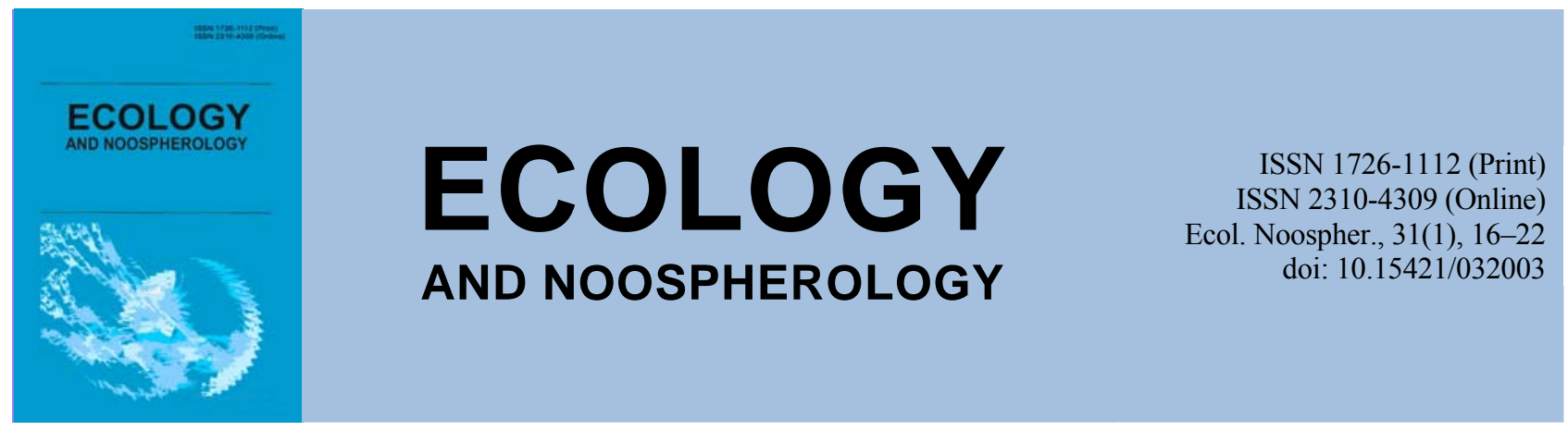

\title{
Structural and aggregate composition features of southern variant natural forest edaphotopes of Ukrainian steppe zone
}

\author{
V. A. Gorban, K. S. Kuptsova, N. S. Ostrianyn, O. G. Tetiukha
}

Oles Honchar Dnipro National University, Dnipro, Ukraine

Article info

Received 20.05.2020

Received in revised form

28.05.2020

Accepted 06.06.2020

Oles Honchar Dnipro

National University,

Gagarin Ave., 72, Dnipro,

49010, Ukraine.

Tel.: +38-050-362-45-90

E-mail:vad01@ua.fm
Gorban, V. A., Kuptsova, K. S., Ostrianyn, N. S., \& Tetiukha, O. G. (2020). Structural and aggregate composition features of southern variant natural forest edaphotopes of Ukrainian steppe zone. Ecology and Noospherology, 31(1), 16-22. doi:10.15421/032003

The natural forests of the southern variant of the steppe zone of Ukraine (according to the classification of O. L. Belgard) are located on the territory of the former porous part of the Dnieper. The properties of edaphotopes of these forests were studied in detail by the staff of the Comprehensive expedition of the Oles Honchar Dnipro National University for the study of forests in the steppe zone of Ukraine (A. P. Travleev, N. A. Bilova, A. A. Dubina, K. M. Bozhko). However, there are no data on the structural and aggregate composition of the genetic horizons of edaphotopes of natural forests of the southern variant of the steppe zone of Ukraine, established by classical methods of determination. This work is devoted to the coverage of these features. As a result of research it is established that the best conditions for the formation of structural aggregates are characteristic of the upper horizons of all studied soils and especially for the forest chernozem in the conditions of northern exposure. The highest content of agronomically valuable structural aggregates is characterized by forest chernozem in the conditions of northern exposure of the ravine, the lowest - meadow-forest soil of thalweg, and forest chernozem in the conditions of southern exposure occupies an intermediate value. The eluvial horizons of ravine edaphotopes differ most contrastingly from the illuvial horizons in the conditions of northern and southern exposures. Eluvial horizons are characterized by a reduced fraction content of $>10 \mathrm{~mm}$ and increased values of the structural coefficient compared to illuvial horizons. In the thalweg, these differences are not so clear. The upper horizons have an increased content of water-resistant fraction size $>5 \mathrm{~mm}$ compared to the horizons below. With depth in all studied edaphotopes there is an increase in the content of the fraction size $<0.25 \mathrm{~mm}$ with depth. Among the upper horizons, the highest content of water-resistant fraction size $>5 \mathrm{~mm}$ and the lowest content of fraction $<0.25 \mathrm{~mm}$ differs meadow-forest soil in thalweg conditions. Very close to the meadowforest soil in terms of the values of the respective fractions is forest chernozem in the conditions of northern exposure. Forest chernozem in the conditions of southern exposure differs by the lowest content of water-resistant fraction size $>5 \mathrm{~mm}$ and the highest content of fraction size $<$ $0.25 \mathrm{~mm}$ among all studied soils. Eluvial horizons of forest chernozems of northern and southern exposures differ from illuvial horizons by reduced content of water-resistant fractions of $>5$ and 5-3 mm. The eluvial horizons of the meadow-forest soil of the thalweg differ from the illuvial horizon by a sharp decrease in the content of the water-resistant fraction of $1-0.5 \mathrm{~mm}$. A comparative analysis of the structural and aggregate composition of the studied edaphotopes revealed that the best conditions for the formation of agronomically valuable fractions are characteristic of the forest chernozem of the northern exposure. As a result of comparing the characteristics of eluvial and illuvial horizons, it was found that the change of eluvial process to illuvial is accompanied by a sharp decrease in forest chernozems content of agronomically valuable fractions during dry sieving, as well as an increase in water resistance. In meadow-forest soils, this transition is characterized by a sharp decrease in the content of agronomically valuable fractions in the illuvial horizon during wet sieving compared to the eluvial horizon.

Keywords: natural forests; forest chernozem; meadow-forest soil; structural and aggregate composition; faction; water resistance 


\title{
Особливості структурно-агрегатного складу едафотопів байрачних лісів південного варіанта степової зони України
}

\author{
В. А. Горбань, К. С. Купцова, Н. С. Острянин, О. Г. Тетюха
}

Дніпровський начіональний університет імені Олеся Гончара, Дніпро, Украӥна

Байраки південного варіанта степової зони України (за класифікацією О. Л. Бельгарда) розташовані на території колишньої порожистої частини Дніпра. Властивості едафотопів цих байраків детально досліджені співробітниками Комплексної експедиції Дніпровського національного університету імені Олеся Гончара $з$ дослідження лісів степової зони України (А. П. Травлєєв, Н. А. Білова, А. О. Дубина, К. М. Божко). Разом з тим відсутні дані щодо структурно-агрегатного складу генетичних горизонтів едафотопів цих байраків, встановленого за класичними методиками визначення. Саме висвітленню цих особливостей і присвячена дана робота. У результаті досліджень установлено, що найкращі умови для формування структурних агрегатів характерні для верхніх горизонтів усіх досліджуваних грунтів і особливо для чорнозему лісового пробної площі в умовах північної експозиції. Елювіальні горизонти байрачних едафотопів найбільш контрастно відрізняються від ілювіальних горизонтів в умовах північної та південної експозиції. Елювіальні горизонти характеризуються зменшеним умістом фракції розміром $>10$ мм та збільшеними значеннями коефіцієнта структурності порівняно з ілювіальними горизонтами. У тальвегу ці відмінності виявляються не так чітко. Верхні горизонти відрізняються збільшеним умістом водостійкої фракції розміром > 5 мм порівняно 3 горизонтами, що розташовані нижче. 3 глибиною в усіх досліджених едафотопах спостерігається зростання вмісту фракції розміром $<0,25$ мм 3 глибиною. Елювіальні горизонти чорноземів лісових північної та південної експозицій відрізняються від ілювіальних горизонтів зменшеним умістом водостійкої фракції розміром > 5 та 5-3 мм. Елювіальні горизонти лучно-лісового грунту тальвегу відрізняються від ілювіального горизонту різким зменшенням умісту водостійкої фракції розміром $1-0,5$ мм. Порівняльний аналіз структурноагрегатного складу досліджених едафотопів виявив, що найкращі умови для формування агрономічно цінних фракцій характерні для чорнозему лісового північної експозиції.

Ключові слова: байрак; чорнозем лісовий; лучно-лісовий грунт; структурно-агрегатний склад; фракція; водостійкість

\section{Ветуп}

Як відомо, на правому березі річки Дніпра, на території колишньої порожистої частини, історично сформувалися природні байрачні ліси 3 унікальною північною, кавказькою та середземноморською флорою (Travleyev et al., 2005). Відповідно до класифікації О. Л. Бельгарда (Belgard, 1971) ці ліси відносяться до південного варіанта байрачних лісів степової зони України. Як зазначають А. П. Травлєєв та ін. (Travleyev et al., 2005), походження загадкового феномену - байрачних лісів $є$ до цього часу природною загадкою, незважаючи на те, що в науковій літературі є понад десяток гіпотез та припущень 3 цього приводу. Однак неодмінним є те, що байрачні ліси та переліски, які характеризуються особливим мікрокліматом, гідрологічним режимом, специфічними фіто- та зоокомпонентами, своєрідними грунтами та підстилками 3 яскраво вираженими властивостями чорноземного типу грунтоутворення, $€$ складною збалансованою багатогранною біогеоценотичною системою (Travleyev et al., 2005).

Результати дослідження едафотопів байрачних лісів південного варіанта наведено в фундаментальній роботі Н. А. Білової та А. П. Травлєєва (Belova, Travleyev, 1999). Зокрема, авторами наведено детальні макроморфологічні та мікроморфологічні описи, проаналізовано вміст та склад гумусу, наведено результати аналізу водної витяжки, особливості гранулометричного складу, фізикохімічні властивості. Установлено, що структурні агрегати верхніх гумусових горизонтів чорноземів лісових містять значну масу копролітів, що зумовлює формування сприятливого повітряно-водного режиму в цих грунтах. Під природними байрачними лісами в грунтах спостерігається значне переважання вмісту гумусу порівняно $з$ грунтами під степовою рослинністю. Водні витяжки не виявляють ознак засолення. Аналіз розподілу гранулометричних фракцій за горизонтами свідчить про найбільшу чутливість до переміщення фракції розміром менше 0,001 мм. У грунтово-поглинальному комплексі чорноземів лісових спостерігається домінування двохвалентних катіонів - кальцію та магнію (Belova, Travleyev, 1999).
Грунтово-геоботанічна характеристика та особливості агрегатного складу едафотопів байрачних лісів південного варіанта наведено в роботі К. М. Божко (Bozhko, 2007). Автором установлено, що найвищі показники структурності притаманні гумусовим горизонтам нижніх третин схилів північної та південної експозицій, а також тальвегу байраку. Відмічається, що з глибиною показники коефіцієнта структурності знижуються. Великий уміст окремостей 0,5-2 мм, що мають суттєвий позитивний вплив на режим та властивості грунтів, характерний для гумусових горизонтів північної експозиції, тальвегу та нижньої третини південної експозиції (Bozhko, 2007).

Мікроморфологічні властивості едафотопів південного варіанта байрачних лісів освітлені в роботі К. М. Божко (Bozhko, 2011). Автором установлено, що в грунтах верхньої третини схилу в $15^{\circ}$ північної експозиції коефіцієнт структурності має досить високі показники. Показники водостійкості сягають $85 \%$ у верхньому горизонті (0-10 см), з глибиною поступово знижуються до $73 \%$ на глибині 70 см і продовжують знижуватися до $30 \%$ на глибині 1 м (Bozhko, 2011).

Таким чином, у науковій літературі наявна інформація про певні особливості едафотопів байрачних лісів південного варіанта степової зони України, однак відсутні дані щодо їх структурно-агрегатного складу, який відіграє важливе значення у забезпеченні біогеоценотичних функцій грунтів (Medvedev, 2008; Gorban, 2016), зокрема дослідженого за генетичними горизонтами із застосуванням стандартизованих методик його визначення. Саме дослідженню цих особливостей едафотопів байраків південного варіанта і присвячена наша робота.

\section{Об’єкти та методи досліджень}

Грунтові зразки для аналізу структурно-агрегатного складу едафотопів байрачних лісів південного варіанта відбиралися в умовах трьох пробних площ, закладених на середніх третинах північної та південної експозицій, а також у тальвегу байраку Військового, який розташований поблизу с. Військове (Солонянський р-н Дніпропетровської обл.). Нижче наводимо опис пробних площ та закладених грунтових профілів. 
Пробна площа № 1 розташована в середній третині схилу $3^{\circ}$ північної експозиції.

Тип лісового біогеоценозу - природна свіжа пакленова діброва 3 дубовим широкотрав'ям (Dn2). Тип лісорослинних умов - суглинок свіжий (СГ2). Зволоження атмосферно-транзитне. Тип світлової структури тіньовий. Тип деревостану - 10 Д.ч., вік - 80-90 років, зімкнутість - 0,8-0,9, третьої вікової стадії розвитку 3 кущовим підліском з клену польового.

Макроморфологічна характеристика трунтового профілю:

H1el 0-10 см Перший гумусовий горизонт, елювіальний, темно-сірий, свіжуватий, дрібнозернистої структури, суглинистий, дуже пухкий, корененасичений. Перехід поступовий за щільністю.

H2el 10-30 см Другий гумусовий горизонт, елювіальний, темно-сірий, сухуватий, зернисто-горіхуватої структури, суглинистий, щільніший за попередній, корененасиченість менша, ніж у попередньому. Перехід поступовий за щільністю.

$\mathrm{H} 3 \mathrm{el}$ 30-50 см Третій гумусовий горизонт, елювіальний, темно-сірий, сухий, зернисто-горіхуватої структури, суглинистий, щільний. Перехід різкий за забарвленням та структурою.

Hil 50-100 см Гумусовий горизонт, ілювіальний, сірий, сухий, призматичної структури, суглинистий, щільний. На структурних агрегатах помітно присипку $\mathrm{SiO}_{2}$. Перехід поступовий за забарвленням та структурою.

Phil 100-150 см Перехідний горизонт, світло-сірий 3 буруватим відтінком, призматичної структури, суглинистий, щільний. На структурних агрегатах помітно присипку $\mathrm{SiO} 2$. Перехід поступовий за забарвленням.

Р 150-170 см Материнська порода - лесоподібний суглинок. Світло-сірий з бурим відтінком, без вираженої структури, суглинистий, щільний. Помітно присипку $\mathrm{SiO}_{2}$.

Назва грунту - лісовий чорнозем сильновилугований середньолесивований середньогумусовий на делювіальних відкладах.

Пробна площца № 2 розташована на дні тальвегу. Глибина грунтових вод $-1,0$ м.

Тип лісового біогеоценозу - природний вологий осичняк (ВС3). Тип лісорослинних умов - суглинок вологий (СГЗ). Зволоження - транзитне атмосферногрунтове. Тип світлової структури - освітлений. Тип деревостану - 10 Осика, зімкнутість $-0,7-0,8$, третьої вікової стадії розвитку без кущового підліску.

Макроморфологічна характеристика трунтового профілю:

H1el 0-10 см Перший гумусовий горизонт, елювіальний, темно-сірий, вологуватий, дрібнозернистої структури 3 окремими грудками, суглинистий, дуже пухкий, корененасичений. Перехід поступовий за щільністю.

H2el 10-40 см Другий гумусовий горизонт, елювіальний, темно-сірий, вологуватий, дрібнозернистої структури, суглинистий, пухкий, корененасиченість менша, ніж у попередньому. Перехід поступовий за щільністю.

H3el 40-70 см Третій гумусовий горизонт, елювіальний, темно-сірий, вологий, зернистої структури, суглинистий, щільніший, ніж попередній. Перехід поступовий за щільністю та структурою. На структурних агрегатах помітно присипку $\mathrm{SiO}_{2}$.

Hil 70-100 см Гумусовий горизонт, ілювіальний, сірий з буруватим відтінком, мокрий, без вираженої структури, суглинистий, щільний, за консистенцією схожий на пасту. Помітно присипку $\mathrm{SiO}_{2}$. Вода.

Назва грунту - лучно-лісовий чорноземоподібний сильновилугований середньогумусовий на делювіальних відкладах.

Пробна площца № 3 розташована в середній третині схилу $16^{\circ}$ південної експозиції.

Тип лісового біогеоценозу - природна сухувата чорнокленова діброва 3 фіалкою шершавою (Е1). Тип лісорослинних умов - суглинок сухуватий (СГ1). Зволоження - атмосферне. Тип світлової структури тіньовий. Тип деревостану - 10 Д.ч., зімкнутість $-0,6-0,7$, третьої вікової стадії розвитку 3 кущовим підліском 3 клену татарського.

Макроморфологічна характеристика трунтового профілю:

H1el 0-10 см Перший гумусовий горизонт, елювіальний, темно-сірий, сухуватий, дрібнозернистопилуватої структури, суглинистий, пухкий, корененасичений. Перехід поступовий за щільністю.

H2el 10-34 см Другий гумусовий горизонт, елювіальний, темно-сірий, сухуватий, зернисто-горіхуватої структури, суглинистий, щільніший за попередній, корененасиченість менша, ніж у попередньому. Перехід поступовий за щільністю.

H3el 34-54 см Третій гумусовий горизонт, елювіальний, темно-сірий, сухий, зернисто-горіхуватої структури, суглинистий, щільний. Перехід різкий за забарвленням та структурою.

Hil 54-92 см Гумусовий горизонт, ілювіальний, темносірий 3 буруватим відтінком, сухий, призматичної структури, суглинистий, щільний. На структурних агрегатах добре помітно присипку $\mathrm{SiO}_{2}$. Перехід поступовий за забарвленням та структурою.

Phkil 92-120 см Перехідний горизонт, сірий з темнобурим відтінком, призматичної структури, суглинистий, щільний. На структурних агрегатах добре помітно присипку $\mathrm{SiO}_{2}$. Перехід поступовий за забарвленням. Скипання з глибини $108 \mathrm{~cm}$.

Pk 120-150 см Материнська порода - лесоподібний суглинок. Сірий 3 бурим відтінком, без вираженої структури, суглинистий, щільний. Помітно присипку $\mathrm{SiO}_{2}$.

Назва грунту - чорнозем лісовий вилугований середньолесивований середньогумусовий на лесових відкладах.

Визначення структурно-агрегатного складу досліджених грунтів виконували ситовим методом (сухе та мокре просіювання) у модифікації Н. I. Саввінова (DSTU 4744:2007) (Medvedev, 2008).

\section{Результати та їх обговорення}

У результаті аналізу структурно-агрегатного складу чорнозему лісового пробної площі № 1, розташованої на північній експозиції байраку, установлено, що в горизонті H1el відсутня фракція розміром > 10 мм (табл. 1), а переважними є фракції розміром $10-7$ та $7-5$ мм (21,7 та $22,1 \%$ відповідно). Найменшим умістом характеризуються фракції розміром $0,5-0,25$ та $<0,25$ мм $(1,7$ та $1,8 \%$ відповідно). У горизонті H2el переважною $є$ фракція розміром 10-7 мм (16,3\%), а мінімальний уміст припадає на фракції розміром $0,5-0,25$ та $<0,25$ мм $(4,5$ та $4,0 \%$ відповідно). Горизонт Н3el відрізняється збільшеним умістом фракції розміром > 10 мм $(18,1 \%)$ та зменшеним умістом фракції розміром $0,5-0,25$ та $<0,25$ мм $(5,4$ та $6,3 \%$ відповідно). У горизонтах Hil, Phil та $\mathrm{P}$ спостерігається різке зростання вмісту фракції розміром $>10$ мм $(31,1,30,6$ та 26,3 \% відповідно) порівняно 3 елювіальними горизонтами H1el, H2el та H3el, що може бути характерною ознакою ілювіальних генетичних горизонтів чорноземів лісових. Найменший уміст в ілювіальних горизонтах Hil та Phil, як і в елювіальних горизонтах H1el, H2el та H3el, припадає на фракції розміром $0,5-0,25$ та $<0,25$ мм. Розрахунок коефіцієнта структурності свідчить, що найкращими умовами для утворення структурних агрегатів відрізняються елювіальні горизонти, особливо горизонт H1el. Коефіцієнт структурності в цьому горизонті дорівнює 54,5 , а вже 3 горизонту $\mathrm{H} 2 \mathrm{el}$ спостерігається різке зниження його величин. Найменші значення коефіцієнта структурності характерні для ілювіальних горизонтів. 
Таблиця 1

Агрегатний склад едафотопів байраку Військового

\begin{tabular}{|c|c|c|c|c|c|c|c|c|c|c|c|}
\hline \multirow[b]{2}{*}{$\begin{array}{c}\text { Гене- } \\
\text { тичний } \\
\text { горизонт }\end{array}$} & \multirow[b]{2}{*}{$\begin{array}{c}\text { Глибина, } \\
\text { см }\end{array}$} & \multicolumn{9}{|c|}{ Уміст фракцій (мм), \% } & \multirow[b]{2}{*}{$\begin{array}{l}\text { Коефі- } \\
\text { цієнт } \\
\text { структур } \\
\text { ності }\end{array}$} \\
\hline & & $\stackrel{\circ}{\wedge}$ & ఏ̊ & $i$ & $\hat{n}$ & iे & స & ñ & 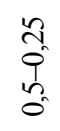 & $\stackrel{n}{\hat{\theta}}$ & \\
\hline \multicolumn{12}{|c|}{ Пробна площа № 1 - чорнозем лісовий (північна експозиція байраку) } \\
\hline H1el & $0-10 \mathrm{~cm}$ & 0,0 & 21,7 & 22,1 & 17,7 & 15,7 & 13,3 & 6,0 & 1,7 & 1,8 & 54,5 \\
\hline $\mathrm{H} 2 \mathrm{el}$ & $10-30 \mathrm{~cm}$ & 14,4 & 16,3 & 14,5 & 9,8 & 12,2 & 13,9 & 10,4 & 4,5 & 4,0 & 4,4 \\
\hline H3el & $30-50 \mathrm{~cm}$ & 18,1 & 12,0 & 10,3 & 10,8 & 12,2 & 14,3 & 10,4 & 5,4 & 6,3 & 3,1 \\
\hline Hil & $50-100 \mathrm{~cm}$ & 31,1 & 10,8 & 9,1 & 9,7 & 11,1 & 11,9 & 8,5 & 4,1 & 3,8 & 1,9 \\
\hline Phil & $100-150 \mathrm{~cm}$ & 30,6 & 12,4 & 13,6 & 9,6 & 10,5 & 10,8 & 6,5 & 2,9 & 3,2 & 2,0 \\
\hline $\mathrm{P}$ & $150-170 \mathrm{~cm}$ & 26,3 & 16,1 & 10,5 & 8,7 & 10,4 & 10,9 & 7,1 & 4,4 & 5,8 & 2,1 \\
\hline \multicolumn{12}{|c|}{ Пробна площа № 2 - лучно-лісовий грунт (тальвег байраку) } \\
\hline H1el & $0-10 \mathrm{~cm}$ & 25,6 & 21,2 & 16,9 & 11,6 & 11,0 & 8,0 & 3,8 & 1,0 & 0,9 & 2,8 \\
\hline $\mathrm{H} 2 \mathrm{el}$ & $10-40 \mathrm{~cm}$ & 49,8 & 16,6 & 9,3 & 8,2 & 7,0 & 5,6 & 2,3 & 0,6 & 0,5 & 1,0 \\
\hline H3el & $40-70 \mathrm{~cm}$ & 60,1 & 12,4 & 7,6 & 6,3 & 5,6 & 4,5 & 2,1 & 0,6 & 0,8 & 0,6 \\
\hline Hil & $70-100 \mathrm{~cm}$ & 63,8 & 10,2 & 6,0 & 4,3 & 4,7 & 5,0 & 3,3 & 1,2 & 1,4 & 0,5 \\
\hline \multicolumn{12}{|c|}{ Пробна площа № 3 - чорнозем лісовий (південна експозиція байраку) } \\
\hline H1el & $0-10 \mathrm{~cm}$ & 16,0 & 25,3 & 18,9 & 12,4 & 11,7 & 8,6 & 4,3 & 1,3 & 1,3 & 4,8 \\
\hline $\mathrm{H} 2 \mathrm{el}$ & $10-34 \mathrm{~cm}$ & 30,4 & 11,1 & 11,2 & 7,8 & 9,0 & 11,7 & 10,2 & 5,0 & 3,6 & 1,9 \\
\hline $\mathrm{H} 3 \mathrm{el}$ & $34-54 \mathrm{~cm}$ & 25,6 & 17,3 & 14,2 & 8,9 & 10,5 & 10,1 & 7,4 & 3,1 & 2,9 & 2,5 \\
\hline Hil & $54-92$ см & 43,1 & 15,2 & 11,4 & 7,7 & 8,7 & 7,6 & 3,9 & 1,2 & 1,2 & 1,3 \\
\hline Phkil & $92-120 \mathrm{~cm}$ & 38,8 & 13,1 & 10,7 & 6,5 & 8,0 & 8,8 & 6,5 & 3,6 & 4,1 & 1,3 \\
\hline $\mathrm{Pk}$ & $120-150 \mathrm{~cm}$ & 21,7 & 21,5 & 10,5 & 8,6 & 10,4 & 11,2 & 7,5 & 3,6 & 5,0 & 2,8 \\
\hline
\end{tabular}

Аналіз структурно-агрегатного складу лучно-лісового грунту пробної площі № 2, розташованої в тальвегу байраку, свідчить про переважання в горизонті Hlel фракцій розміром > 10 та $10-7$ мм $(25,6$ та $21,2 \%$ відповідно). Найменший уміст у цьому горизонті припадає на фракції розміром $0,5-0,25$ та $<0,25$ мм (1,0 та $0,9 \%$ відповідно). У горизонтах H2el, H3el та Hil спостерігається переважання фракції розміром > 10 мм (49,8, 60,1 та 63,8 \% відповідно). Найменший уміст у цих горизонтах фракцій розміром $<0,25$ мм. В ілювіальному горизонті Нil спостерігається незначне збільшення вмісту фракцій розміром $>10$ та $<0,25$ мм порівняно 3 елювіальними горизонтами. У результаті розрахунку коефіцієнта структурності встановлено, що горизонт Hlel відрізняється найкращими умовами для формування структурних агрегатів. Коефіцієнт структурності в цьому горизонті дорівнює 2,8 , а 3 горизонту $\mathrm{H} 2 \mathrm{el}$ спостерігається різке його зменшення, з мінімальними значеннями в ілювіальному горизонті $(0,5)$.

Дослідження структурно-агрегатного складу чорнозему лісового пробної площі № 3, розташованої на південній експозиції байраку, виявили, що в горизонті H1el переважає фракція розміром $10-7$ мм (25,3 \%). Найменший уміст у цьому горизонті припадає на фракції розміром $0,5-$ 0,25 та $<0,25$ мм (1,3 та $1,3 \%$ відповідно). У горизонтах H2el та Н3el переважас фракція розміром > 10 мм (30,4 та $25,6 \%$ відповідно), а найменшим умістом характеризуються фракції розміром $0,5-0,25$ та $<0,25$ мм. Горизонти Hil та Phkil відрізняються переважанням фракції розміром > 10 мм (43,1 та $38,8 \%$ відповідно), при цьому ці значення $\epsilon$ значно більшими порівняно 3 елювіальними горизонтами H1el, H2el та H3el. У горизонтах Hil та Phkil найменший уміст також припадає на фракції розміром $0,5-0,25$ та $<0,25$ мм. У горизонті $\mathrm{Pk}$ спостерігається переважання фракцій розміром > 10 та 10 7 мм (21,7 та 21,5\%), найменший уміст характерний для фракцій розміром $0,5-0,25$ та $<0,25$ мм. Розрахунок коефіцієнта структурності для цього грунту виявив, що найкращі умови для формування структурних агрегатів склалися в горизонті H1el. Коефіцієнт структурності цього горизонту дорівнює 4,8, 3 глибиною спостерігається зменшення його значень. При цьому елювіальні горизонти відрізняються збільшеними величинами коефіцієнта структурності порівняно з ілювіальними горизонтами.
Таким чином, в результаті аналізу структурноагрегатного складу едафотопів байраку встановлено, що найкращі умови для формування структурних агрегатів характерні для верхніх горизонтів усіх досліджуваних грунтів і особливо для чорнозему лісового пробної площі № 1 в умовах північної експозиції. Найбільшим умістом агрономічно цінних структурних агрегатів характеризується чорнозем лісовий в умовах північної експозиції байраку, найменшим - лучно-лісовий грунт тальвегу, а чорнозем лісовий в умовах південної експозиції займає проміжне значення. За оціночними градаціями, наведеними в роботі (Teorii.., 2007), враховуючи значення коефіцієнта структурності, усі генетичні горизонти чорнозему лісового північної експозиції відрізняються відмінним агрегатним станом; у лучно-лісовому грунті тальвегу горизонт H1el - відмінним, горизонт H2el добрим, горизонти H3el тa Hil - незадовільним агрегатним станом; у чорноземі лісовому південної експозиції горизонти H1 el, H2el та H3el - відмінним, горизонти Hil та Phkil - добрим агрегатним станом. Елювіальні горизонти байрачних едафотопів найбільш контрастно відрізняються від ілювіальних горизонтів в умовах північної та південної експозицій. Елювіальні горизонти характеризуються зменшеним умістом фракції розміром $>10$ мм та збільшеними значеннями коефіцієнта структурності порівняно 3 ілювіальними горизонтами. У тальвегу ці відмінності виявляються не так чітко.

Аналіз чорнозему лісового пробної площі № 1 виявив, що в горизонті Hlel максимальний уміст водостійких структурних агрегатів (табл. 2) припадає на фракцію розміром > 5 мм $(27,0 \%)$. Уміст водостійких фракцій розміром 5-3, 3-2 та 2-1 мм практично однаковий $(12,3$, 12,3 та $12,8 \%$ відповідно), дещо меншим умістом відрізняються водостійкі фракції розміром $1-0,5$ та $0,5-$ 0,25 мм (6,4 та $6,8 \%$ відповідно). У горизонті H2el також виявлено наявність водостійкої фракції розміром $>5$ мм $(7,1 \%)$ з одночасним збільшенням умісту фракції розміром $<0,25$ мм. Горизонт $\mathrm{H} 3 \mathrm{el}$ відрізняється відсутністю водостійкої фракції розміром > 5 мм та збільшенням умісту фракції розміром $<0,25$ мм порівняно з горизонтом H2el. В ілювіальних горизонтах Hil та Phil спостерігається майже повна відсутність водостійких фракцій розміром $>5$, $5-3,3-2$ мм та зростання вмісту фракції розміром $<0,25$ мм. 
Таблиця 2

Водостійкість агрегатів едафотопів байраку Військового

\begin{tabular}{|c|c|c|c|c|c|c|c|c|}
\hline \multirow{2}{*}{$\begin{array}{c}\text { Генетичний } \\
\text { горизонт }\end{array}$} & \multirow{2}{*}{ Глибина, см } & \multicolumn{7}{|c|}{ Уміст фракцій (мм), \% } \\
\hline & & $>5$ & $5-3$ & $3-2$ & $2-1$ & $1-0,5$ & $0,5-0,25$ & $<0,25$ \\
\hline \multicolumn{9}{|c|}{ Пробна площа № 1 - чорнозем лісовий (північна експозиція байраку) } \\
\hline H1el & $0-10 \mathrm{~cm}$ & 27,0 & 12,3 & 12,3 & 12,8 & 6,4 & 6,8 & 22,4 \\
\hline $\mathrm{H} 2 \mathrm{el}$ & $10-30 \mathrm{~cm}$ & 7,1 & 4,0 & 5,0 & 9,4 & 25,5 & 18,3 & 30,7 \\
\hline $\mathrm{H} 3 \mathrm{el}$ & $30-50 \mathrm{~cm}$ & 0,1 & 0,7 & 1,8 & 6,2 & 20,8 & 26,3 & 44,1 \\
\hline Hil & $50-100 \mathrm{~cm}$ & 0,0 & 0,1 & 0,0 & 3,6 & 16,5 & 32,2 & 47,5 \\
\hline Phil & $100-150 \mathrm{~cm}$ & 0,0 & 0,0 & 0,2 & 1,4 & 6,5 & 39,4 & 52,4 \\
\hline $\mathrm{P}$ & $150-170 \mathrm{~cm}$ & 0,0 & 0,0 & 0,2 & 0,7 & 2,4 & 39,5 & 57,2 \\
\hline \multicolumn{9}{|c|}{ Пробна площа № 2 - лучно-лісовий грунт (тальвег байраку) } \\
\hline H1el & $0-10 \mathrm{~cm}$ & 28,8 & 11,4 & 10,1 & 10,4 & 11,9 & 8,6 & 18,7 \\
\hline $\mathrm{H} 2 \mathrm{el}$ & $10-40 \mathrm{~cm}$ & 2,2 & 3,9 & 4,1 & 16,9 & 28,0 & 16,5 & 28,4 \\
\hline $\mathrm{H} 3 \mathrm{el}$ & $40-70 \mathrm{~cm}$ & 0,8 & 0,6 & 1,8 & 3,0 & 27,2 & 27,5 & 39,0 \\
\hline Hil & $70-100 \mathrm{~cm}$ & 0,4 & 0,6 & 1,4 & 2,8 & 7,8 & 23,1 & 63,8 \\
\hline \multicolumn{9}{|c|}{ Пробна площа № 3 - чорнозем лісовий (південна експозиція байраку) } \\
\hline H1el & $0-10 \mathrm{~cm}$ & 9,8 & 11,5 & 9,1 & 12,2 & 16,4 & 13,1 & 27,8 \\
\hline $\mathrm{H} 2 \mathrm{el}$ & $10-34 \mathrm{~cm}$ & 2,3 & 0,3 & 1,9 & 5,1 & 16,9 & 24,5 & 49,0 \\
\hline $\mathrm{H} 3 \mathrm{el}$ & $34-54 \mathrm{~cm}$ & 0,0 & 0,6 & 0,1 & 2,0 & 12,6 & 21,3 & 63,4 \\
\hline Hil & $54-92 \mathrm{~cm}$ & 0,0 & 0,1 & 0,2 & 1,9 & 8,4 & 21,1 & 68,3 \\
\hline Phkil & $92-120 \mathrm{~cm}$ & 0,5 & 0,1 & 0,3 & 1,9 & 7,7 & 15,7 & 73,8 \\
\hline $\mathrm{Pk}$ & $120-150 \mathrm{~cm}$ & 0,0 & 0,0 & 0,1 & 1,0 & 4,0 & 15,8 & 79,1 \\
\hline
\end{tabular}

В ілювіальному горизонті Hil, який межує з елювіальним горизонтом H3el, спостерігається зменшення вмісту водостійкої фракції розміром $1-0,5$ мм. Максимальний уміст фракції розміром $<0,25$ мм виявлено в горизонті $\mathrm{P}$ $(57,2 \%)$.

У результаті аналізу лучно-лісового грунту пробної площі № 2 встановлено, що в горизонті H1el (табл. 2) спостерігається максимальний уміст водостійкої фракції розміром > 5 мм $(28,8 \%)$. Горизонти H2el та H3el відрізняються зменшенням умісту водостійких фракцій розміром $>5,5-3,3-2$ мм з одночасним зростанням умісту водостійких фракцій розміром $1-0,5,0,5-0,25$ та $<0,25$ мм порівняно 3 горизонтом H1el. У горизонті Hil спостерігається різке зменшення вмісту водостійкої фракції розміром $1-0,5$ мм (7,8 \% порівняно з $27,2 \%$ в горизонті $\mathrm{H} 3 \mathrm{el})$ та різке збільшення вмісту фракції розміром $<0,25$ мм (63,8 \% порівняно з 39,0 \% в горизонті H3el).

Дослідження чорнозему лісового пробної площі № 3 виявило, що горизонт Hlel відрізняється збільшеним умістом водостійких фракцій розміром $>5,5-3,3-2,2-1$ мм та зменшеним умістом фракції розміром $<0,25$ мм порівняно 3 іншими генетичними горизонтами. У горизонті H2el спостерігається різке зменшення вмісту водостійкої фракції розміром > 5 мм (2,3 \% порівняно з 9,8 \% в горизонті H1el) та збільшення вмісту фракції розміром $<0,25$ мм (49,0\% порівняно з 27,8\% в горизонті H1 el). Горизонт Н3el відрізняється відсутністю водостійкої фракції розміром $>5$ мм, зменшенням умісту водостійкої фракції розміром $1-0,5$ мм та збільшенням умісту фракції розміром $<0,25$ мм. В ілювіальних горизонтах Hil та Phkil спостерігається майже повна відсутність водостійких фракцій розміром $>5,5-3,3-2$ мм, зменшення вмісту водостійкої фракції розміром $1-0,5$ мм та збільшення вмісту фракції розміром $<0,25$ мм. Максимальний уміст фракції розміром $<0,25$ мм виявлено в горизонті Р $(79,1 \%)$.

У результаті аналізу водостійких структурних агрегатів едафотопів байраку встановлено, що верхні горизонти відрізняються збільшеним умістом водостійкої фракції розміром $>5$ мм порівняно з горизонтами, що розташовані нижче. 3 глибиною в усіх досліджених едафотопах спостерігається зростання вмісту фракції розміром $<0,25$ мм з глибиною. Серед верхніх горизонтів найбільшим умістом водостійкої фракції розміром $>5$ мм та найменшим умістом фракції $<0,25$ мм відрізняється лучно-лісовий грунт пробної площі № 2 в умовах тальвегу. Дуже близьким до лучно-лісового грунту за значеннями відповідних фракцій є чорнозем лісовий пробної площі № 1 в умовах північної експозиції. Чорнозем лісовий пробної площі № 3 в умовах південної експозиції відрізняється найменшим умістом водостійкої фракції розміром $>5$ мм та найбільшим умістом фракції розміром $<0,25$ мм серед усіх досліджених грунтів. Елювіальні горизонти чорноземів лісових пробних площ № 1 та 3 відрізняються від ілювіальних горизонтів зменшеним умістом водостійких фракцій розміром > 5 та 5-3 мм. Елювіальні горизонти лучно-лісового грунту пробної площі № 2 відрізняються від ілювіального горизонту різким зменшенням умісту водостійкої фракції розміром 1-0,5 мм. За оціночними градаціями, наведеними в роботі (Теorii.., 2007), у чорноземі лісовому північної експозиції горизонти H1el та H2el характеризуються відмінною водостійкістю, усі інші горизонти - доброю; у лучно-лісовому грунті тальвегу горизонти $\mathrm{H} 1 \mathrm{el}$, H2el та H3el мають відмінну водостійкість, а горизонт Hil - задовільну; у чорноземі лісовому південної експозиції горизонти H1el та H2el відрізняються відмінною водостійкістю, горизонти $\mathrm{H} 3 \mathrm{el}$ та Hil - задовільною, горизонти Phkil та Pk - недостатньо задовільною водостійкістю.

У результаті порівняння характеристик структурноагрегатного складу (Teorii.., 2007) едафотопів байраку встановлено, що найбільший уміст агрономічно цінних фракцій при сухому просіюванні властивий чорноземам лісовим північної та південної експозицій $(98,2$ та 82,6 \% відповідно у верхньому горизонті), а найменший - лучнолісовому грунту тальвегу (73,6 \% у верхньому горизонті). 3 глибиною спостерігається зменшення цього показника (табл. 3). Найбільший уміст агрономічно цінних фракцій при мокрому просіюванні характерний лучно-лісовому грунту тальвегу (81,3 \% у верхньому горизонті), а найменший - чорнозему лісовому в умовах південної експозиції (72,2 \% у верхньому горизонті). Чорнозем лісовий в умовах північної експозиції займає проміжне значення за величиною цього показника. Уміст агрономічно цінних фракцій найбільший в чорноземах лісових північної та південної експозицій (126,5 та 114,4 \% відповідно у верхньому горизонті), найменший - у лучно-лісовому грунті тальвегу (90,5 \% у верхньому горизонті). Найбільші значення критерію водоміцності виявлено у верхньому горизонті чорнозему лісового південної експозиції (523,8 \%), а найменші - у верхньому горизонті чорнозему лісового північної експозиції (170,5 \%). Лучно-лісовий грунт тальвегу за цим показником займає проміжне значення. 
Таблиця 3

Порівняльна характеристика структурного складу едафотопів байраку Військового

\begin{tabular}{|c|c|c|c|c|}
\hline $\begin{array}{c}\text { Генетичний } \\
\text { горизонт }\end{array}$ & $\begin{array}{c}\text { Уміст агрономічно } \\
\text { цінних фракцій } \\
\text { при сухому просіюванні } \\
\text { (сума фракцій } \\
\text { 10,0-0,25 мм), \% }\end{array}$ & $\begin{array}{c}\text { Уміст агрономічно } \\
\text { цінних фракцій } \\
\text { при мокрому } \\
\text { просіюванні } \\
\text { (сума фракцій більше } \\
\text { 0,25 мм), \% }\end{array}$ & $\begin{array}{c}\text { Уміст агрономічно цінних } \\
\text { фракцій, } \\
\text { за С. І. Долговим } \\
\text { та П. У. Бахтіним } \\
\text { (співвідношення даних } \\
\text { сухого та мокрого } \\
\text { просіювання за сумою } \\
\text { агрегатів розміром } \\
\text { 0,25-10,0 мм), \% } \\
\end{array}$ & $\begin{array}{c}\text { Критерій АФІ } \\
\text { або критерій } \\
\text { водоміцності } \\
\text { (відношення суми } \\
\text { агрегатів } 1,0-0,25 \text { мм при } \\
\text { мокрому та сухому } \\
\text { просіюванні), \% }\end{array}$ \\
\hline \multicolumn{5}{|c|}{ Пробна площа № 1 - чорнозем лісовий (північна експозиція байраку) } \\
\hline H1el & 98,2 & 77,6 & 126,5 & 170,5 \\
\hline $\mathrm{H} 2 \mathrm{el}$ & 81,6 & 69,3 & 117,7 & 294,1 \\
\hline $\mathrm{H} 3 \mathrm{el}$ & 75,6 & 55,9 & 135,2 & 297,0 \\
\hline Hil & 65,1 & 52,5 & 124,0 & 385,5 \\
\hline Phil & 66,2 & 47,6 & 139,1 & 489,0 \\
\hline $\mathrm{P}$ & 68,0 & 42,8 & 158,9 & 366,4 \\
\hline \multicolumn{5}{|c|}{ Пробна площа № 2 - лучно-лісовий грунт (тальвег байраку) } \\
\hline H1el & 73,6 & 81,3 & 90,5 & 427,4 \\
\hline $\mathrm{H} 2 \mathrm{el}$ & 49,6 & 71,6 & 69,3 & 1506,4 \\
\hline $\mathrm{H} 3 \mathrm{el}$ & 39,1 & 61,0 & 64,1 & 2036,4 \\
\hline Hil & 34,8 & 36,2 & 96,1 & 685,1 \\
\hline \multicolumn{5}{|c|}{ Пробна площа № 3 - чорнозем лісовий (південна експозиція байраку) } \\
\hline H1el & 82,6 & 72,2 & 114,4 & 523,8 \\
\hline $\mathrm{H} 2 \mathrm{el}$ & 66,0 & 51,0 & 129,4 & 272,6 \\
\hline $\mathrm{H} 3 \mathrm{el}$ & 71,5 & 36,6 & 195,4 & 324,1 \\
\hline Hil & 55,7 & 31,7 & 175,7 & 583,0 \\
\hline Phkil & 57,1 & 26,2 & 217,9 & 233,5 \\
\hline $\mathrm{Pk}$ & 73,3 & 20,9 & 350,7 & 178,1 \\
\hline
\end{tabular}

Таким чином, порівняльний аналіз структурноагрегатного складу досліджених едафотопів виявив, що найкращі умови для формування агрономічно цінних фракцій характерні для чорнозему лісового північної експозиції. $\mathrm{y}$ результаті порівняння характеристик елювіальних та ілювіальних горизонтів встановлено, що зміна елювіального процесу на ілювіальний супроводжується різким зменшенням в чорноземах лісових умісту агрономічно цінних фракцій при сухому просіюванні, а також збільшенням критерію водоміцності. В лучно-лісовому грунті цей перехід характеризується різким зменшенням в ілювіальному горизонті вмісту агрономічно цінних фракцій при мокрому просіюванні порівняно з елювіальним горизонтом.

За оціночними градаціями, наведеними в роботі (Teorii.., 2007), за умістом агрономічно цінних фракцій (за C. І. Долговим та П. У. Бахтіним), у чорноземі лісовому північної експозиції горизонт $\mathrm{H} 1 \mathrm{el}$ характеризується відмінною агрономічно цінною структурою, горизонти H2el та H3el - доброю, інші горизонти - задовільною агрономічно цінною структурою; у лучно-лісовому грунті тальвегу горизонт H1el має добру агрономічно цінну структуру, горизонт H2el - задовільну, інші горизонти незадовільну агрономічно цінну структуру; у чорноземі лісовому південної експозиції горизонт Н1еl відрізняється відмінною агрономічно цінною структурою, інші горизонти - задовільною агрономічно цінною структурою. За значеннями критерію водоміцності (критерію АФІ) усі горизонти чорнозему лісового північної експозиції характеризуються доброю водоміцністю агрегатів; у лучно-лісовому грунті тальвегу горизонт H1el має добру водоміцність агрегатів, горизонти H2el та H3el - відмінну, горизонт Hil - дуже добру водоміцність агрегатів; у чорнозему лісовому горизонт $\mathrm{H} 1 \mathrm{el}$ відрізняється дуже доброю водоміцністю агрегатів, інші горизонти - доброю. Виходячи 3 наведених даних, ми вважаємо, що критерій АФІ не зовсім коректно відображає особливості структурно-агрегатного складу досліджених едафотопів.
Отримані результати у загальному вигляді погоджуються 3 даними Н. А. Білової та А. П. Травлєєва (Belova, Travleyev, 1999), К. М. Божко (Bozhko, 2007, 2011), отриманих під час вивчення досліджуваних едафотопів байрачних лісів південного варіанта.

\section{Висновки}

1. Найкращий структурно-агрегатний склад характерний для верхніх горизонтів досліджуваних едафотопів, особливо відрізняється чорнозем лісовий в умовах північної експозиції.

2. Найбільший уміст агрономічно цінних структурних агрегатів виявлено в чорноземі лісовому північної експозиції.

3. Елювіальні горизонти байрачних едафотопів відрізняються зменшеним умістом фракції розміром $>10$ мм та збільшеними значеннями коефіцієнта структурності порівняно з ілювіальними горизонтами.

4. Верхні горизонти досліджених едафотопів відрізняються збільшеними значеннями водостійкості структурних агрегатів порівняно 3 нижніми горизонтами, що відображається в збільшенні з глибиною вмісту фракції розміром $<0,25$ мм.

5. Елювіальні горизонти чорноземів лісових північної та південної експозицій відрізняються від ілювіальних горизонтів зменшеним умістом водостійкіх фракцій розміром $>5$ та 5-3 мм.

6. Елювіальні горизонти лучно-лісового грунту тальвегу відрізняються від ілювіального горизонту різким зменшенням умісту водостійкої фракції розміром 1-0,5 мм.

7. Найкращі умови для формування агрономічно цінних фракцій характерні для чорнозему лісового північної експозиції.

8. Зміна елювіального процесу на ілювіальний супроводжується різким зменшенням в чорноземах лісових умісту агрономічно цінних фракцій при сухому просіюванні, а також збільшенням критерію водоміцності. 


\section{References}

Belgard, A. L. (1971). Stepnoe lesovedenie [Steppe forestry]. Forestry industry, Moscow (in Russian).

Belova, N. A., Travleyev, A. P. (1999). Estestvennye lesa i stepnye pochvy (ecologiia, mikromorfologiia, genesis) [Forest and steppe soils (ecology, micromorphology, genesis)]. Dnipropetrovsk (in Russian).

Bozhko, K. M. (2007). Ekologo-biologichna i gruntovogeobotanichna kharakterystyka pivdennogo variantu bairachnykh lisiv pivdenno-skhidnoi Ukrainy [Ecologicalbiological and soil-geobotanical characteristics of the southern variant of riparian forests of south-eastern Ukraine]. Questions of steppe forestry and forest land reclamation, 11(36), 75-89 (in Ukrainian).

Bozhko, K. M. (2011). Mikromorfologichni vlastyvosti edafotopiv urochychsha Viyskova balka (pivdennyy variant bayrachnykh lisiv stepovoy zony Ukrainy [Micromorphological characteristics of the ravine edaphotopes that exist in a natural landmark «Vijskova balka»]. Gruntoznavstvo, 12, 3-4, 69-77 (in Ukrainian).

Gorban, V. A. (2016). Rol struktury v obespechenii biogeotsenoticheskikh funktsiy pochv [The role of the structure to provide biogeocenotic soil functions]. Ecology and Noospherology, 27, 3-4, 89-96 (in Russian).

Medvedev, V. V. (2008). Struktura pochvy (metody, genesis, klassifikatsiia, evolyutsia, geografiia, monitoring, okhrana) [Soil structure (methods, genesis, classification, evolution, geography, monitoring, protection)]. Kharkov, 13 tipografiia (in Russian).

Teorii i metody fiziki pochv (2007) [Theories and techniques of soil physics]. Ed. E. V. Shein, L. O. Karpachevskij. Moscow (in Russian).

Travleyev, A. P., Bilova, N. A., Bogovin, A. V., Dubina, A. O. (2005). Bajrachnye lesa byvshej porozhystoj chasti Dnepra sostavnaya chast ekologicheskoj seti yuga Ukrainy [Valley forests of the previous Dnipro river rapids - as component of south Ukraine ecological net]. Ecology and noospherology, 16, 3-4, 75-94 (in Russian). 